\title{
Single factorial experimental design for decolorizing anaerobically treated distillery spent wash using cladosporium cladosporioides
}

\author{
${ }^{1 *}$ R. Ravikumar; ${ }^{1}$ N. S. Vasanthi; ${ }^{2}$ K. Saravanan \\ ${ }^{1}$ Department of Biotechnology, Bannari Amman Institute of Technology, Sathyamangalam, Erode District - 638401 , \\ Tamilnadu, India \\ ${ }^{2}$ Department of Chemical Engineering, Kongu Engineering College, Perundurai, Erode District -638052, Tamilnadu, \\ India
}

Received 13 May 2010; $\quad$ revised 10 August 2010; accepted 20 November 2010; $\quad$ available online 1 December 2010

\begin{abstract}
ABSTARCT: This study presents the standardization of nutrient concentration, $\mathrm{pH}$ and temperature required to decolorize the anerobically treated distillery spent wash using the fungus Cladosporium cladosporioides. Experiments were carried out to measure the decolorization of distillery spent wash effluent and it was found to be effective in acidic environment. From the results it was observed that a maximum color reduction of $52.6 \%$ and Chemichal Oxygen Demand. removal of $62.5 \%$ were achieved. The optimum conditions required for the growth of the fungus was found to be $5 \mathrm{~g} / \mathrm{L}$ of fructose, $3 \mathrm{~g} / \mathrm{L}$ of peptone, $5 \mathrm{pH}$ and $35^{\circ} \mathrm{C}$. It was also observed that during the process a maximum of $1.2 \mathrm{~g}$ of fungal growth was attained. Decolorizing ability of the fungus was confirmed using spectrophotometer and High Performance Liquid Chromatography analysis. Single factorial experimental design was used to optimize the parameters. Apart from decolorization it was observed that fungus also has the ability to degrade the spent wash efficiently. This investigation could be an approach towards control of environmental pollution and health hazards of people in and around the distillery unit.
\end{abstract}

Key words: Biodegradation; Biomass Chemical Oxygen demand; Fructose; Melanoidin

\section{INTRODUCTION}

The waste water from molasses based alcohol distilleries is known as molasses spent wash. When released in aquatic system, leads to reduction of sunlight penetration in rivers, lakes and thereby reducing the photosynthetic activity. Disposal on land cause reduction in soil alkalinity, manganese availability and inhibits seed germination (Agarwal, et al., 1994; FitzGibbon et al., 1995; Ling et al., 2009). In molasses based distilleries anaerobic treatment is an accepted practice and various high rate anaerobic reactor designs have been tried at pilot and full-scale operation (Lata et al., 2002). However, anaerobic ally treated effluent still contains high concentrations of organic pollutants and as such cannot be discharged directly (Nandy et al., 2002). Spent wash contains about $2 \%$ of dark brown recalcitrant pigment called melanoidin which has an empirical formula of $\mathrm{C}_{17-18} \mathrm{H}_{26-}$ ${ }_{27} \mathrm{O}_{10} \mathrm{~N}$ and molecular weight between 5000 and 40,000

\4Corresponding Author Email: ravi_cbe1@rediffmail.com Tel.: +99429522 6255; Fax: +99429522 3775
Da. Melanoidins is known as a natural browning polymer produced by Maillard reaction between amino and carbonyl groups of organic matters and is closely related to humic substances in the natural environment. (Aoshima et al., 1985; Fujita et al., 2000; Manishankar et al., 2004; Samarghandi et al., 2007). Physicochemical treatment with active activated carbon was investigated to removal the color causing components (mainly melanoidins) from biomethanated distillery spent wash by (Satyawali, et al., 2008; Saetang and Babel, 2009 ) but was in effective for application to large scale as it requires a pretreatment with sulphuric acid, phosphoric acid, nitric acid and hydrochloric acid for the adsorbent .However, recently an increasing attention has been directed towards utilization of microbial activities for decolorisation of effluents (Pant and Adholeya, 2007; Nwuche; Ugoji, 2008 and 2010). Several fungi such as Phanerochaete chrysosporium JAG-40, Aspergillus species, A.gaisen, P.pinophilum and Emericella nidulans have been used for the 
treatment of distillery spent wash (Dahiya et al., 2001; Thakkar et al., 2006; Pant et al., 2007; Pazouki et al., 2008; Cuthbertson et al., 2010; Singh et al., 2010).But these organism were not able to maintain a consistency in the result and hence not been implemented in the distillery industries. In order to avoid the drawbacks, an organism which can be isolated from the same distillery site and which requires minimum nutrients for its growth, potiential to decolorize, degrade melanoidine present in spent wash is needed. Optimization of process parameters required for the particular organism for its growth plays a major role in the degradation process.

It is evident from the report that Cladosporium cladosporioides has high potential to decolorize two model dye and also showed maximum decolorization when tested with 1:2 metal complex acid blue 193 dye. (Vijayakumar et al., 2006; Antonella Anastasi et al.,

2009; Malakootian M. et al., 2009; Shah et al., 2009). Hence in this report an effort was made to use the fungus, Cladosprium cladosporioides which was isolated from the spentwash disposal sites of distillery unit to degrade and decolorize the anerobically treated distillery spent wash. Since the use of statistics based experimental design in the optimization of the biotreatment processes has been well documented (Annadurai et al., 2008; Madukasi et al., 2010). In this paper sequential statistics based experimental designs were applied with single factor to optimize the range of medium concentration, initial $\mathrm{pH}$ and temperature for obtaining maximum percentage decolorization. So far no work was carried out using Cladosporium cladosporioides for decolorizing Anerobically treated distillery spent wash. This study was carried out at Bioprocess research laboratory, Department of Biotechnology, Bannari Amman Institute of Technology, Sathyamangalam, India during the period of February 2009 to November 2009.

\section{MATERIALS AND METHODS}

Anaerobically Treated Distillery Spent wash (ADSW)

The molasses spent wash after biomethanation from anaerobic digester was collected aseptically from distillery division of Bannari Amman Sugars Limited, Periyapuliyur, Erode District, and Tamilnadu., India. The spentwash was centrifuged at $4200 \mathrm{Xg}$ for $15 \mathrm{~min}$ before use to remove the suspended solids and stored at 4 ${ }^{\circ} \mathrm{C}$.( Pazouki et al., 2008) The stored ADSW was filtered through (What man No: 42) filter paper and was diluted with deioinized distilled water (Millipore Direct - Q.3 UV). The analysis of different physico-chemical parameters like Color, odour, $\mathrm{Ph}$, Biochemical oxygen demand (BOD), Chemical oxygen demand (COD), total sugars, total dissolved solids (TDS), sulphates, phosphorous and free chlorine were analysed for employing standard methods for examination of water and waste water. (APHA, 1995) and is shown in Table1.

\section{Isolation and Screening of Cladosprium cladosporioides}

Soil sample was collected from the Anerobically Treated Distillery Spent Wash (ADSW) disposal sites of Periyapuliyu. Several organisms were isolated from the soil sample using serial dilution method and was then screened for its decolorization ability of ADSW using Giant Colony and Shake Flask method. (Dahiya et al., 2001). During the screening process Cladosprium cladosporioides showed largest zone of decolorization (Ravikumar et al., 2010) and hence was selected for this investigation to optimize the process parameters using single factorial experiment. Conidal spore structure of Cladosprium cladosporioides was observed through Light microscope photomicrograph and was shown in Fig. 1. The selected strain was allowed to grow separately in a agar plate containing PDA and was transferred to slant culture for storing it to long duration. The Potato dextrose agar medium used was prepared by taking $200 \mathrm{~g}$ of peeled and sliced potato with one litre distilled water which was then subjected to steaming for 30 min. The extract was filtered and made up to a volume of 1 liter. To this $20 \mathrm{~g}$ of dextrose, $0.1 \mathrm{~g}$ of yeast extract, $20 \mathrm{~g}$ of agar and $1 \%$ diluted ADSW were added (Chavan, et al., 2006; Mullai et al., 2007). Fungal

Table 1: Physico chemical characteristics ADSW before treatment

\begin{tabular}{ll}
\hline Parameters & Magnitude \\
\hline Color & Greenish dark brown \\
Odour & Burnt sugar \\
$\mathrm{pH}$ & 7.20 \\
$\begin{array}{l}\text { Biochemical oxygen demand (BOD) } \\
\text { (mg/L) }\end{array}$ & $5000-6500$ \\
$\begin{array}{l}\text { Chemical oxygen demand (COD) } \\
\text { (mg/L) }\end{array}$ & 34,800 \\
Total dissolved solids(TDS) (mg/L) & $4500-4620$ \\
Sulphates (mg/L) & 160 \\
Potassium (mg/L) & 850 \\
free chlorine (mg/L) & 800 \\
\hline
\end{tabular}




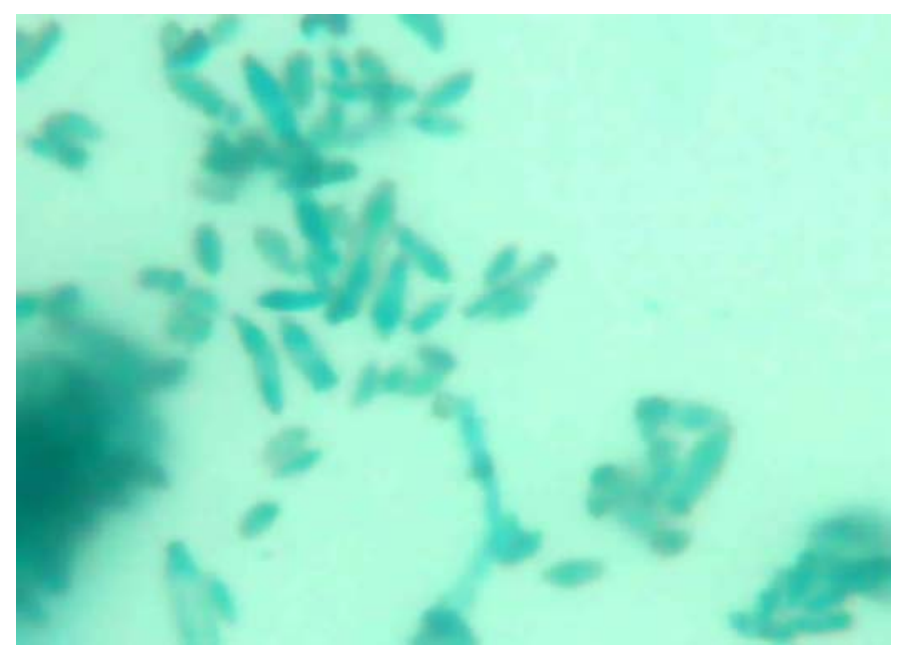

Fig. 1: Light microscope photomicrograph of Cladosprium cladosporioides sowing conidial spore structure

inoculum for the batch process was prepared by transferring a loopful of strain from the slant into a 250 $\mathrm{mL}$ conical flask containing $50 \mathrm{~mL}$ Potato dextrose broth and was incubated in a orbatory shaker at $250 \mathrm{rpm}$ at $30{ }^{\circ} \mathrm{C}$ for 7 days until phase of spores formation was observed. Reseeding was carried out every 25 days to maintain the active population. In order to avoid the extended growth of population $30 \% \mathrm{HCl}$ was added to acidify the medium. Growth medium used for counting spores alone was prepared with solution and method (Jimenez et al., 2004). Acclimatization study was carried out at room temperature with $15 \%$ diluted ADSW as stock solution which was the dilution made upto optical density value of maximum percentage decolorization obtained from the previous work carried out in treating synthetic melanoidine distillery spent wash It was performed by gradually exposing Cladosprium cladosporioides to the higher concentration of ADSW and was consecutively transferred into the nutrient medium. During the process nutrient broth concentration was decreased from $90 \%(\mathrm{w} / \mathrm{v})$ to $0 \%$ $(\mathrm{w} / \mathrm{v})$ and finally the organism was provided with spent wash solution as sole source of nutrient. (Gopinath et al., 2009).

\section{Experimental}

In any microbial decolorization process, medium components of carbon, nitrogen source, $\mathrm{pH}$ and temperature were considered to be important parameters affecting the process. Batch experiment was conducted in a series of $500 \mathrm{mLconical}$ flask containing $100 \mathrm{~mL}$ of $15 \%$ diluted ADSW cultivation medium supplemented with carbon and nitrogen source. $5 \mathrm{~mL}$ of inoculum ( $8 \times 10^{6}$ spores, $5^{\text {th }}$ day) from $250 \mathrm{~mL}$ conical flask was transferred into each flask and was incubated in a rotary incubator shaker at $250 \mathrm{rpm}$ for 10 days. Effect of varying the concentration of Fructose $(5,10,15,20 \mathrm{~g} / \mathrm{L})$, peptone $(1,3,5,7 \mathrm{~g} / \mathrm{L}), \mathrm{pH}(4,5,6,7,8)$ and temperature $\left(30,35,40,45{ }^{\circ} \mathrm{C}\right)$ on the percentage decolorization of the ADSW medium were studied by single factorial experiment. In each experiment only one factor, was changed with the other factors remaining constant. Role of optimization was confirmed based on the results of biodegradability index improvement when the process condition was optimized for tannery effluent. (Aboulhassan et al., 2004). The initial conditions required for the experiment was taken from the previous work carried out in treating synthetic melanoidine distillery spent wash. A $5 \mathrm{~mL}$ of the aliquot was withdrawn for every 8 hour time interval and centrifuged for assaying decolorization for 10 days. Experiment was repeated with the optimized parameters and COD reduction with residual color was observed. The observance was measured as decrease in optical density of supernatant of treated ADSW medium at $475 \mathrm{~nm}$ (Krishna Prasad et al., 2009; Seyis, et al., 2009) on UV Spectrophotometer (Perkin Elmer Model: Lambda 35). 
pH determination was made by using Digital portable pH meter (Model pt-10P, Sartorius). COD was measured by using Open Reflux (APHA, 1995). The OD value was measured and the percentage decolorization was calculated using the formulae:

$\%$ Decolorization $=($ Initial OD - Final OD $) * 100 /$ (Initial OD)

\section{HPLC analysis of treated ADSW}

HPLC analysis was carried out at quality control and assurance laboratory, Centre for Pharmacognosy and Pharmaceutics FRLHT, Bangalore, India. Decolorization of ADSW was monitored by HPLC (Shimadzu). $10 \mathrm{~mL}$ of samples were taken, and centrifuged, filtered through 0.45 $\mu \mathrm{m}$ membrane filter (Millipore). Filtered sample was analysed using mobile phase consisting of acetonitryl and methanol (45:55) (HPLC grade) with $1 \mathrm{~mL}$ glacial acid and $0.5 \mathrm{~mL}$ sodium acetate. (Chavan, et al.,2006; Ramya, et al.,2007) The sample was eluted using C-18; reverse phase column of $5 \mu \mathrm{m}$ SGE, 250 x $4.6 \mathrm{~mm}$ SS. Resultant peak was analyzed with UV -detector $475 \mathrm{~nm}$. The flow rate of the mobile phase was $1 \mathrm{~mL} / \mathrm{min}$.

\section{RESULTS AND DISCUSSION}

Effect of fructose concentration on color removal

The influence of fructose on percentage of decolorization was studied by varying the fructose concentration from $5 \mathrm{~g} / \mathrm{L}$ to $20 \mathrm{~g} / \mathrm{L}$ while other parameters temperature $35{ }^{\circ} \mathrm{C}, 4 \mathrm{pH}$ and $1 \mathrm{~g} / \mathrm{L}$ of peptone was maintained constant. From Fig. 1 it is observed that during the initial period of 2 days there is no significant change in color removal of the spent wash and maximum of $42.6 \%$ decolorization was achieved at fructose concentration of $5 \mathrm{~g} / \mathrm{L}$ on the $7^{\text {th }}$ day and no significant change on the remaining days. It was also observed that when the concentration was increased above $5 \mathrm{~g} / \mathrm{L}$ concentration the percentage decolorization decreased. This is due to large mycelia growth and lignolytic activity of laccase enzyme produced. Laccase enzyme was tested using guaiacol and found to be oxidized to form reddish brown zone similar to the results obtained by (Viswanathan et al., 2008).Effect of laccase in the degradation of DDT showed the potential of the enzyme present in the white rod fungi.(Zhao et al., 2009) Reports reveal that anaerobically treated distillery spent wash medium was a better laccase inducer medium than the mineral media. Laccase production by Aspergillus heteromorphus was studied using anaerobically treated distillery spent wash (ADSW). During the initial phase of growth organism utilities easily available carbon source added as medium and later on starts to degrade spent wash components for carbon source. Although spent wash contains large amount of sugar, its easily metabolisable carbon source is almost negligible. So addition of readily available external carbon source like fructose is required for its metabolism. It was reported that the percentage decolorization of ADSW was highest when glucose was fed as carbon source with flavodon flavus isolated from a marine habitat (Raghukumar and Rivonkar., 2001) In addition to that effect it also enhanced the degradation of xenophobic compounds. It was also observed from that maximum color removal is favored for $5 \mathrm{~g} / \mathrm{L}$ of fructose concentration with the biomass increased to $0.7 \mathrm{~g} / \mathrm{L}$ till 8th day. Above this concentration there was no significant change in the percentage of color removal resulting an inhibiting effect to the enzyme.

\section{Effect of peptone concentration on color removal}

The influence of peptone on percentage of decolorization was studied by varying the peptone concentration from $1 \mathrm{~g} / \mathrm{L}$ to $7 \mathrm{~g} / \mathrm{L}$ while other parameters temperature $35^{\circ} \mathrm{C}, 4 \mathrm{pH}$ and $5 \mathrm{~g} / \mathrm{L}$ of optimum fructose concentration was maintained constant Supplementation of various concentration of peptone in addition to $5 \mathrm{~g} / \mathrm{L}$ of fructose and with ADSW medium was found to be less effective for decolorization and microbial growth. It was reported that among the nitrogen source supplemented along with the carbon source, yeast extract and peptone gave highest growth with decolorization for culture Phanerochaete Chrysosporium (Kumar et al., 1998). It is observed from the Fig. 2 that maximum of $45.6 \%$ decolorization was achieved with concentration of $1 \mathrm{~g} / \mathrm{L}$ attaining $0.72 \mathrm{~g} / \mathrm{L}$ of biomass. At high concentration there was no significance in decolourization due to excess supplementation of nitrogen which inturn leads to inhibition of the source to fungal growth. Similar 


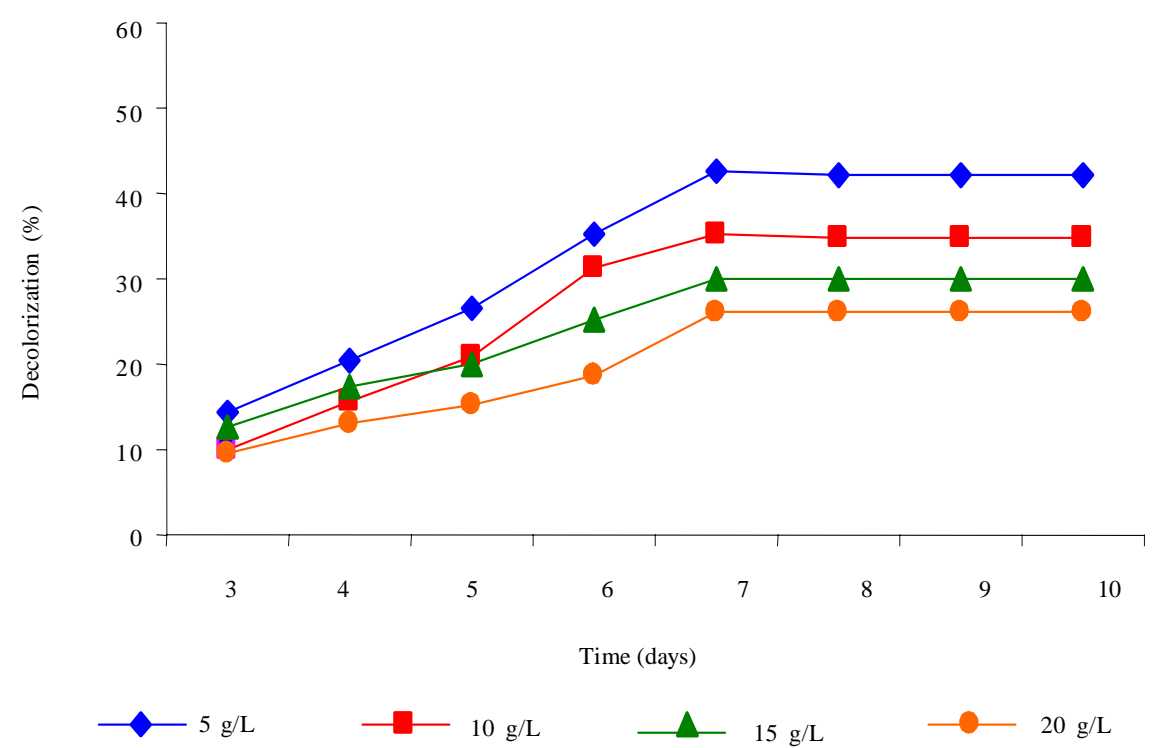

Fig. 2: Effect of fructose concentration on $\%$ decolorization at $35^{\circ} \mathrm{C}, 4 \mathrm{pH}$ and $1 \mathrm{~g} / \mathrm{L}$ of peptone

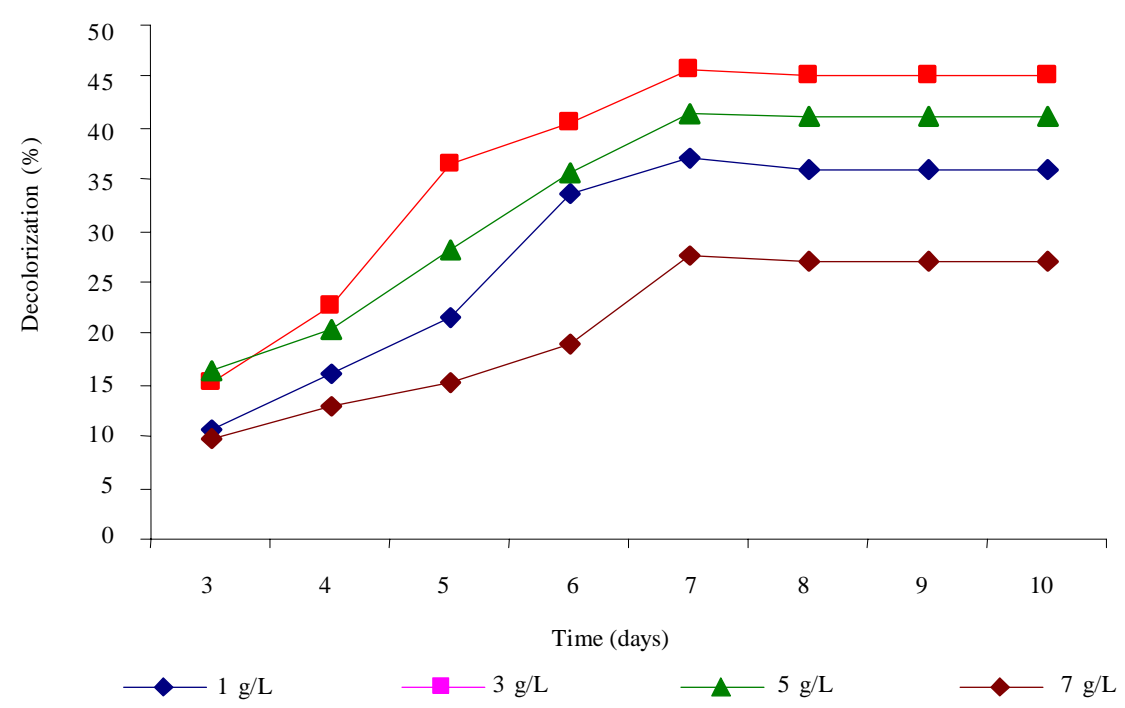

Fig. 3: Effect of Peptone concentration on $\%$ decolorization at $35{ }^{\circ} \mathrm{C}, 4 \mathrm{pH}$, at $5 \mathrm{~g} / \mathrm{L}$ of fructose

effect was observed when low concentration of peptone was used as nitrogen source for decolorizing melanoidine pigment present in spent wash using Phanerochaete Chrysosporium (Dahiya. et al., 2001). Laccase production was high on the $7^{\text {th }}$ day and thereafter was inhibited. In contrary to the report by (Viswanathan et al., 2008) that nitrogen source of peptone was the critical factor for efficient laccase production .But in this investigation it was observed that the production was high only at low concentration of nitrogen source compared to carbon source. 


\section{Effect of pH on color removal}

The influence of $\mathrm{pH}$ on percentage of decolorization was studied by varying the $\mathrm{pH}$ from 4 to 8 while other parameters temperature $35^{\circ} \mathrm{C}, 5 \mathrm{~g} / \mathrm{L}$ of optimum fructose concentration and $3 \mathrm{~g} / \mathrm{L}$ of optimum peptone concentration was maintained constant. From Fig. 3 it was observed that maximum color removal of $54.8 \%$ was achieved at $5 \mathrm{pH}$ with $0.96 \mathrm{~g}$ of biomass growth. It was found that the percentage decolorization decreased and did not support the growth with alkaline and neutral conditions. In case of decolorization of molasses Trichoderma species it was concluded that enzymes formed by fungi during the process were effective only in acidic conditions. (Seyis et al., 2009) An increase in color at high $\mathrm{pH}$ was due to the polymerization of melanoidins and higher nutrient utilization. However, overall significant decolorisation

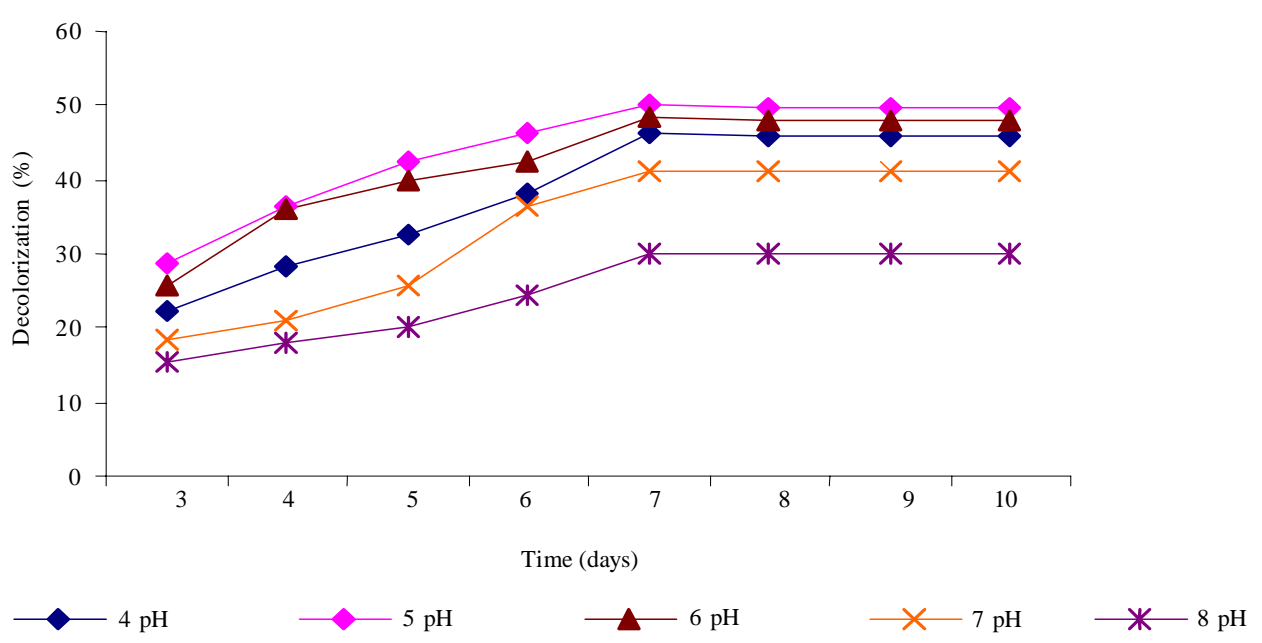

Fig. 4: Effect of $\mathrm{pH}$ on $\%$ decolorization at $35^{\circ} \mathrm{C}, 5 \mathrm{~g} / \mathrm{L}$ of fructose and $3 \mathrm{~g} / \mathrm{L}$ of peptone

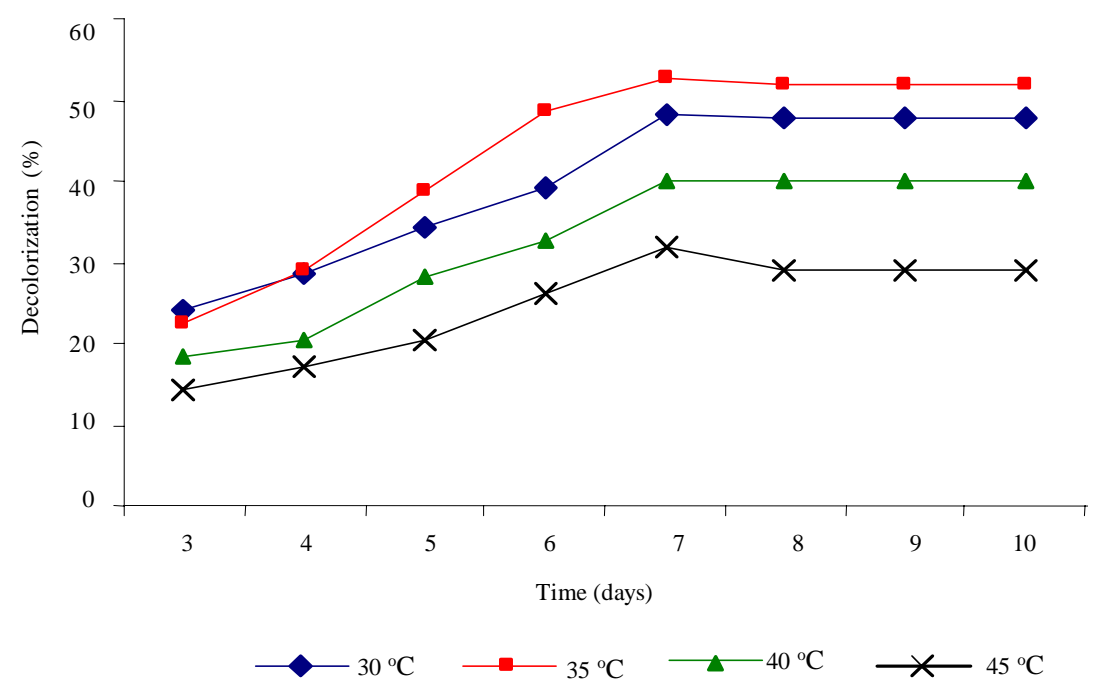

Fig. 5: Effect of temperature on \% decolorization at $5 \mathrm{pH}, 5 \mathrm{~g} / \mathrm{L}$ of fructose and $3 \mathrm{~g} / \mathrm{L}$ of peptone 

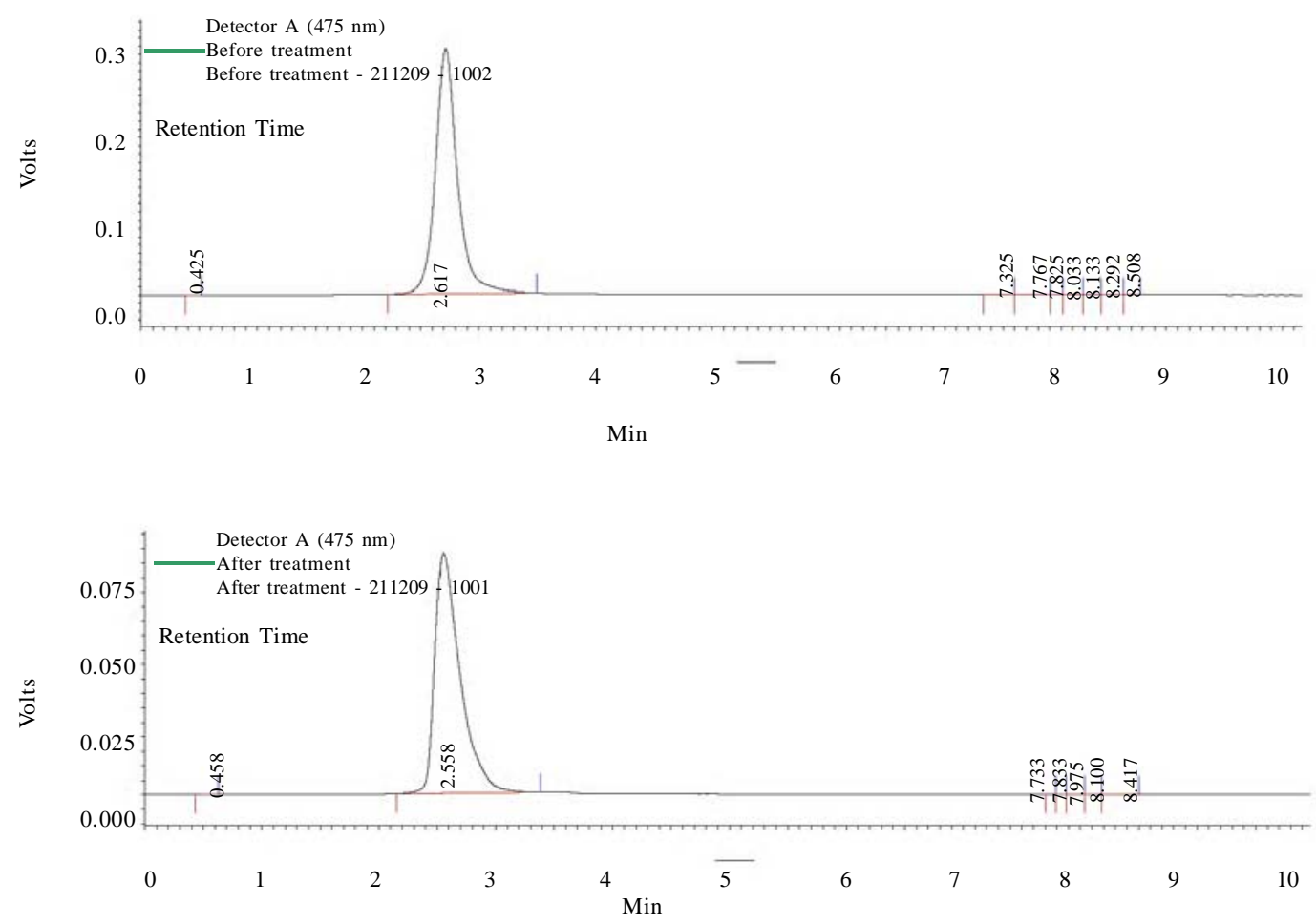

Fig. 6: (a) HPLC analysis for ADSW before treatment showing a maximum peak with 2.617 retention time, 3928110 area and 296296 height. (b) HPLC analysis for ADSW after treatment showing a maximum peak with 2.58 retention time, 1262329 area and 83113 height

was obtained in the optimal range of 5-6 which confirms the significant rol of $\mathrm{pH}$ in color removal. Similar results were reported when soil samples were used as inoculum instead of isolated organisms (Adikane. et al., 2006). (Pazouki et al.,2008) reported that A.fumigatus strain $\mathrm{U}_{\mathrm{B} 2}$ isolated from soil sample were more efficient in decolorizing TDW due to its acquaintance with melanoidin for long period of time and showed maximum percentage of color reduction with optimized $\mathrm{pH}$ 5.6.The report depicts that a maximum growth was obtained between $\mathrm{pH} 5.5$ and 7.0 and on either side of the $\mathrm{pH}$, there was a decrease in the growth of the fungus and simultaneously decreased the percentage when dye was decolorized with Cladosporium Cladosporioides (Vijayakumar et al., 2006).

\section{Effect of temperature on color removal}

The influence of temperature on \% decolorization was studied by varying the temperature from $30^{\circ} \mathrm{C}$ to $45^{\circ} \mathrm{C}$ while other parameters temperature $35^{\circ} \mathrm{C}, 5 \mathrm{~g} / \mathrm{L}$ of optimum fructose concentration and $3 \mathrm{~g} / \mathrm{L}$ of optimum peptone concentration was maintained constant. From Fig. 4 it was observed that highest color removal of $52.6 \%$ was reached at $35^{\circ} \mathrm{C}$. At higher temperature above $35^{\circ} \mathrm{C}$ there was decrease in color which reveals that the organism could not withstand the temperature. A maximum fungal growth of $1.2 \mathrm{~g}$ was observed at the above optimum conditions for an incubation period of 7 days which confirms the biodegradation of the spent wash. The results reveal that the maximum growth stimulation was attained at $35{ }^{\circ} \mathrm{C}$ which is the suitable temperature, C. cladosporioides isolated from the distillery disposal site can withstand .This might be due to their prolonged exposure to that soil and the spent wash. It was observed that with the optimized parameters of $5 \mathrm{pH}, 5 \mathrm{~g} / \mathrm{L}$ of fructose and $3 \mathrm{~g} / \mathrm{L}$ of peptone at $35{ }^{\circ} \mathrm{C}$ for incubation period of 10 days, COD reduction increased to a maximum of $62.5 \%$ 
with residual color attaining $47.4 \%$.This effect was due to the increase in the microbial growth reaching $1.2 \mathrm{~g}$ and biodegradation of the organic matters ,color causing biopolymer melanoidin pigment. When both decolorization and COD reduction was observed as a function of time the result reveals that with the increasing decolorization activity there was remarkable reduction in COD with increase in biomass between 7 to 8 days. This was mainly due to the enzymatic degradation. The tolerance studies at different concentration of spentwash revealed that only organism were able to tolerate up to $15 \%$ of $(\mathrm{v} / \mathrm{v})$ of anerobically treated distillery spentwash concentration. Since the organism was isolated from the spent wash disposal site, it was well acclimatized to the spent wash and was able to consume itself as nutrient source. The HPLC analysis report representing the area, height, retention time, before and after the treatment of ADSW which is shown in Fig. 6 (a) and (b) confirms the biodegradation of melanoidins the main pigment responsible for color. It was observed that a major peak appeared at a retention time of $2.58 \mathrm{~min}$ in treated sample which was less compared to untreated and clearly indicates the ability of the Cladosporium $s p$ to decolorize and degrade the spent wash. The reduction in physicochemical characteristics may be due to degradation of ADSW in the presence of carbon and nitrogen sources through metabolism.

\section{CONCLUSION}

In the present investigation anerobically treated distillery spent wash was decolorized by Cladosprium cladosporioides which was isolated from soil samples of distillery spent wash disposal site. Since the fungus was exposed to the spent was in the soil, they were found to be more effective in the decolorization process. Treatment of spent wash by single organism with minimum medium requirements is more effective .Hence the influence of various parameters such as concentration of fructose, peptone, $\mathrm{pH}$ and temperature on decolourisation of ADSW was studied. The results of COD reduction reveal that the fungus has the ability to degrade the organic matters and melanoidine present in the ADSW under optimum conditions. The developed fungal culture could be used for decolorization of ADSW of distillery industries for their safe utilization in agricultural field and also for industrial purpose. Since the use of an individual treatment alone may not be a complete solution, a hybrid or combination of process is required to achieve the desired target. The Research is under process to find the interaction effect of the parameters to enhance the efficiency of decolorization.

\section{ACKNOWLEDGEMENTS}

This work is the result of Ph.D work of the first author. The author wishes to express their gratitude for the support extended by management of Bannari Amman Distillery Division, Periyapuliyur , Erode District, Tamilnadu., India. for providing us the spent wash and also soil sample. We wish to express our thanks to the management of Bannari Amman Institute of Technology, Sathyamangalam, India for helping us to carry out the research in Bioprocess Laboratory, Department of Biotechnology. We also thank the Foundation for Revitalization of Local Health Traditions (FRLHT), Bangalore, India for the HPLC analysis report. All the authors are cordially wish to express their thanks to the reviews for their valuable suggestions in improving this research work and manuscript.

\section{REFERENCES}

Aboulhassan, M. A.; Souabi, S.; Yaacoubi, A., (2008). Pollution reduction and biodegradability index improvement of tannery effluents. Int. J. Environ. Sci. Tech., 5 (1), 11- 16 (6 pages).

Adikane, H. V.; Dange, M. N.; Selvakumari, K., (2006). Optimization of anaerobically digested distillery molasses spent wash decolorization using soil as inoculum in the absence of additional carbon and nitrogen source. Bioresour. Tech., 97 (16), 2131-2135 (5 pages).

Agarwal, C. S.; Pandey, G. S., (1994). Soil pollution by spent wash discharge: Depletion of manganese (II) and impairment of its oxidation. J. Environ. Biol., 15 (1), $49-53$ (5 pages).

Annadurai, G.; Ling, L. Y.; Lee J. F., (2008). Statistical optimization of medium components and growth conditions by response surface methodology to enhance phenol degradation by Pseudomonas putida. J. Hazard. Mater., 151 (1), 171-178 (8 pages).

Anastasi, A.; Prigione, V.; Casieri, L.; Varese. G. C., ( 2009). Decolourisation of model and industrial dyes by mitosporic fungi in different culture condition. World. J. Microbiol. Biotech., 25 (8), 1363-1374 (12 pages).

Aoshima, I.; Tozawa,Y.; Ohmomo, S.; Udea K., (1985). Production of Decolorizing activity for molasses pigment by Coriolus versicolor Ps4a. Agri. Niol. Chem., 49 (7), 20412045 (8 pages).

APHA, (1995). Standard methods for the examination of water and waste water. $19^{\text {th }}$ ed. Washington, DC (8 pages).

Chavan, M. N.; Kulkarani, M. V.; Zope, V. P.; Mahulikar, P. P., (2006). Microbial degradation of melanoidins in distillery spent wash by indigeneous isolate. Indian J. Biotech., 5 (1), 416-421 (6 pages). 
Cuthbertson, A. G. S.; Blackburn, L. F.; Northing, P.; Luo, W.; Cannon, R. J. C.; Walters, K. F. A., (2010). Chemical compatibility testing of the entomopathogenic fungus Lecanicillium muscarium to control Bemisia tabaci in glasshouse environment. Int. J. Environ. Sci. Tech., 7 (2) 405-409 (5pages).

Dahiya, J.; Sing, D.; Nigam, P.,(2001a). Decolorization of molasses waste water by cells of Pseudomonas fluorescens on porous cellulose carrier. Biores. Tech., 13 (78), 110-114 (8 pages).

Dahiya, J.; Sing, D.; Nigam, P.,(2001b). Decolourisation of synthetic and spent wash melanoidins using the white-rot fungus Phanerochaete chrysosporium JAG-40.Bioresour Tech., (78) 95 - 98 (4 pages).

FitzGibbon, F. J.; Nigam, P.; Sing, D,; Marchant, R., (1995). Biological treatment of distillery waste for pollution remediation. J. Basic. Microbiol., 35 (5), 293-301 (9 pages).

Fujita, M.; Ike, M.; Kavagoshi, Y.; Miyata, N., (2000). Biotreatment persistent substances using effective microorganisms. Wat. Sci. Tech., 42 (12), 86-93 (7 pages).

Gopinath, K.; MeeraShib, H. A.; Muthukumar, K.; Velan, M., (2009). Improved biodegradation of congored by using Bacillus sp. Bioresourse Tech., 100 (2), 670-675 (6 pages).

Jimenez, A. M.; Borja, R.; Martin. A.; Raposo F., (2004). Mathematical modelling of aerobically degradation of vinasses with Penicillium decumbens. Process Biochem., 40 (8), 2805-2811 (7 pages).

Kaushik, G.; Thakur, I. Sh., (2009). Isolation of fungi and optimization of process parameters for decolorization of distillery mill effluent. World. J. Microbiol. Biotech., 25 (6), 157-163 (7 pages).

Krishna Prasad, R.; Srivastava, S. N., (2009). Sorption of distillery spent wash only onto fly ash: Kinetics, mechanism, process design and factorial design. J. Hazard. Mater., 161 (2), 1313-1322 (10 pages).

Kumar, V.; Wati, L.; Nigam, P.; Banat, I. M.; Yadav, B. S.; Singh, D.; Marchant, R., (1998). Decolorization and biodegradation of anerobically digested sugarcane molasses spentwash effluent from biomethanated plant by white-rot fungi.Process biochemestry. 33 (1), 83-88 (6 pages).

Lata, K.; Kansal, A.; Balakrishnan, M.; Rajeswari, K. V.; Kishore V. N.,(2002). Assessment of biomethanation potential of selected industrial organic effluents. Resour. Conserc. Recycl., 35 (3), 147-161 (14 pages).

Ling, T.; Guanghua, Z.; Jun, R., (2009). Effects of chromium on seed germination, root elongation and coleoptile growth in six pulses. Int. J. Environ. Sci. Tech., 6 (4), 571-578 (8 pages).

Madukasi, E. I.; Dai, X.; H, C.; Zhou, J., (2010). Potentials of phototrophic bacteria in treating pharmaceutical wastewater. Int. J. Environ. Sci. Tech., 7 (1) 165-174 (10 pages).

Malakootian, M.; Nouri, J.; Hossaini, H., (2009). Removal of heavy metals from paint industry's wastewater using Leca as an available adsorbent. Int. J. Environ. Sci. Tech., 6 (2) 183-190 (8 pages).

Manishankar, P.; Rani, C.; Viswanathan, S., (2004). Effects of halides in the electrochemical treatment of distillery effluent. Chemosphere., 57 (8), 961-966 (6 pages ).

Mullai, P.; Vishali,S., (2007). Biodegradation of penicillin-G wastewater using Phanerochate chysosporium-An equilibrium and kinetic modeling. Afr. J. Biotech., 6 (12), 1450-1454 (5 pages).

Nandy, T.; Shastry, S.; Kaul S. N., (2002). Wastewater management in cane molasses distillery involving bioresource recovery. J. Environ. Manage., 65 (1), 25-38 (13 pages).

Nwuche, C. O.; Ugoji, E. O., (2008). Effects of heavy metal pollution on the soil microbial activity. Int. J. Environ. Sci. Tech., 5 (3), 409-414 (6 pages).

Nwuche, C. O.; Ugoji, E. O, (2010). Effect of co-existing plant specie on soil microbial activity under heavy metal stress. Int. J. Environ. Sci. Tech., 7 (4), $697-704$ (8 pages).

Pant, D.; Adholeya, A., (2007). Identification, ligninolytic enzyme activity and decolorization potential of two fungi isolated from a distillery effluent contaminated site. Water Air Soil Pollut., 183 (1-4), 165-176 (8 pages).

Pant, D.; Adholeya, A., (2007). Biological approaches for treatment of distillery waste water. A review Bioresour. Tech., 98 (12), 2321-2334 (13 pages).

Pazouki, M.; Shayegan, J.; Afshari, A.,(2008). Screening of microorganisms for decolorization of treated distillery wastewater. Iran. J. Sci. Techn., 32 (B1), 53-60 (8 pages).

Pazouki, M.; Najafpour, G.; Hosein, M. R., (2008). Kinetic models of cell growth, substrate utilization and biodecolorization of distillery wastewater by Aspergillus fumigatus. $\mathrm{U}_{\mathrm{B} 2} 60$. Afr. J. Biotech., 7 (9), 1369-1376 (8 pages).

Raghukumar, C.; Rivonkar, G., (2001) Decolorization of molasses spent wash by white-rot fungus Flavodon flavus, isolated from a marine habitat. Appl. Microbiol. Biotech., 55 (4), 510-514 (5 pages).

Ramya.M.; Anusha, B.; Kalavathy, S.; Devilaksmi, S., (2007). Biodecolorization and biodegradation of reactive blue by Aspergillus sp. Afr. J. Biotech., 6 (12), 1441-1445 (5 pages).

Ravikumar, R.; Monash, P.; Derek Chan, J. C.; Saravanan K., (2010). Microbial decolorization of biomethanate distillery spentwash using Aspergillus nidulans. Asian J. Microbiol. Biotech. Env. Sci., 12 (2), 337-342 (6 pages).

Saetang, J.; Babel, S., (2009). Effect of leachate loading rate and incubation period on the treatment efficiency by $\mathrm{T}$. versicolor immobilized on foam cubes. Int. J. Environ. Sci. Tech., 6 (3), 457-466 (10 pages).

Samarghandi, M. R.; Nouri J.; Mesdaghinia, A. R.; Mahvi, A. H.; Nasseri, S.; Vaezi, F., (2007). Efficiency removal of phenol, lead and cadmium by means of UV/ TiO2/ H2O2 processes. Int. J. Environ. Sci. Tech. 4 (1), 19-26 (8 pages).

Satyawali, Y.; Balakrishnan, M., (2008). Wastewater treatment in molasses-based alcohol distilleries for COD and color removal: A review. J. Environ. Manage. 86 (3), 481-497 (16 pages).

Seyis, I.; Subasing, T., (2009). Screeming of different fungi for decolorization of molasses. Brazilian J. Microbiol., 40 (1), 61-65 (5 pages).

Shah, B. A.; Shah, A. V.; Singh, R. R., (2009). Sorption isotherms and kinetics of chromium uptake from wastewater using natural sorbent material. Int. J. Environ. Sci. Tech., 6 (1) 77-90 (14 pages).

Singh, A.; Bajar, S.; Bishnoi, N. R.; Singh, N., (2010). Laccase production by Aspergillus heteromorphus using distillery spent wash and lignocellulosic biomass. J. Hazard. Mater., 15, 176 (1-3), 79-82 (4 pages). 


\section{R. Ravikumar et al.}

Thakkar, A. P.; Dhamanakar, V.; Kapadnis B., (2006). Biocatalytic decolourisation of molasses by phanerochaete chrysosporium. Biores. Tech., 97 (12), 1387-1391 (44 pages).

Vijayakumar, M. H.; Veeranagouda, Y.; Neelakanteshwar, K.; Karegoudar, T. B., (2006). Decolorization of 1:2 meta complex dye Acid blue 193 by a newly isolated fungus, Cladosporium cladosporioides. World. J. Microbiol. Biotechnol., 22 (2), 157-162 (5 pages).
Viswanath, B.; Subhosh Chandra, M.; Pallavi, H.; Rajasekhar Reddy B., (2008). Screening and assessment of laccase producing fungi isolated from different environmental samples. African J. Biotechnol., 8 (1), 1129-1133 (8 pages).

Zhao, Y. C.; Yi, X. Y.; Zhang, M.; Liu, L.; Ma, W. J., (2010). Fundamental study of degradation of dichlorodiphenyl trichloroethane in soil by laccase from white rot fungi, Int. J. Environ. Sci. Tech., 7 (2), 359-366 (8 pages).

\section{AUTHOR (S) BIOSKETCHES}

Ravikumar, R., Senior Lecturer, Department of Biotechnology, Bannari Amman Institute of Technology, Sathyamangalam, Erode 6384001,Tamilnadu, India, Email: ravi_cbe1@rediffmail.com

Vasanthi, N. S., Professor and Head, Department of Biotechnology, Bannari Amman Institute of Technology, Sathyamangalam, Erode 6384001, Tamilnadu, India, Email:vasanthiuk@yahoo.co.in

Saravanan, K., Professor and Head, Department of Chemical Engineering, Kongu Engineering College, Perundurai, Erode-638 052,Tamilnadu, India, Email: rumisivaesh@yahoo.com

How to cite this article: (Harvard style)

Ravikumar, R.; Vasanthi, N. S.; Saravanan, K., (2011). Single factorial experimental design for decolorizing anaerobically treated distillery spent wash using cladosporium cladosporioides. Int. J. Environ. Sci. Tech., 8 (1), 97-106. 